\title{
Hydraulic conductivity variation in chilean volcanic soils due to wheeling and management
}

\author{
J. Cuevas ${ }^{1,2 *}$, R. Horn ${ }^{3,6}$, O. Seguel ${ }^{4}$, J. Dörner ${ }^{5,6}$ \\ ${ }^{1}$ Departamento de Suelos y Recursos Naturales, Facultad de Agronomía, Universidad de Concepción, Chillán. Chile. ${ }^{2}$ Programa \\ de Doctorado, Escuela de Graduados Facultad de Ciencias Agrarias, Universidad Austral, Valdivia. Chile ${ }^{3}$ Institute for Plant \\ Nutrition and Soil Science, Christian Albrechts University, Olshausenstr. 40, D-24118 Kiel, Germany ${ }^{4}$ Departamento de Ingeniería \\ y Suelos, Facultad de Ciencias Agronómicas, Universidad de Chile,Santiago, Chile ${ }^{5}$ Instituto de Ingeniería Agraria, Facultad \\ de Ciencias Agrarias, Universidad Austral, Casilla, Valdivia. Chile. ${ }^{6}$ Centro de Investigación en Suelos Volcánicos, Universidad \\ Austral de Chile, Valdivia, Chile*Corresponding author: josecuevas@udec.cl
}

\begin{abstract}
To describe the effect of wheeling on saturated hydraulic conductivity (ks), undisturbed soil samples from an Andisol were collected at three depths In Chilean soil classification system Andisols are defined as Malihue at the 2 sites minor and mayor mechanical stresses were applied repeatedly and the hydraulic properties determined for all depths.

The saturated hydraulic conductivity Ks was reduced due to wheeling but the magnitude depended on the speed and load during wheeling. In addition, also the pore size distribution was reduced both in total but also in size classes. Smaller values of Ks were observed in Site 2 where low speed and low tire inflation pressure were applied, while the traffic induces a reduction of the pore associated to a reduced functionality of the porous system. To assess these qualitative changes and soil behaviour, measurements like hydraulic conductivity (ks) are a good tool to describe the physical quality of a soil.
\end{abstract}

Keywords: Volcanic ash soil, hydraulic conductivity, soil porosity

\section{Introduction}

It is well known that a well aggregated soil is important for plant development, water availability and balance, gas transport, soil workability as well as soil strength (Reszkowska, et al, 2010). Water flow and solute transport processes in structured soils depend not only on soil porosity and soil texture, but also on pore shape and pore continuity or a negligible small tortuosity (Horton et al., 1994). The rate and direction of water movement through soils is determined by hydraulic potential and hydraulic conductivity (Horgan and Ball, 2005). Nevertheless, because soils are more complex, with twisted and crooked pores, dead-ending or connecting the other pores we need to scale the permeability from the capillary tube model to include increased path length due to crookedness of the path (tortuosity) or lack of connection between points in the soil (connectivity). In theory, the two parameters should be inversely related, with highly connected (or 
highly porous) soils having low tortuosity and vice versa (Vervoort and Cattle, 2003).

Tillage-induced changes in soil properties are difficult to predict concerning the influence on infiltration, redistribution of water within the profile, subsequent evaporation rates, and water availability to crops. The influence of tillage on soil hydraulic properties and infiltration are not always consistent across location and soils. Initially, tillage may have a positive influence on infiltration (Messing and Jarvis, 1993) but this effect is usually transitory and usually leads to a decline in infiltration rates on tilled surfaces as a result of reconsolidation and aggregate disintegration after repeated rainstorms (Moret and Arrué, 2007).

Total porosity often decreased less by compaction than the macroporosity because the microporosity increased (Ellies et al., 2000). Janssen et al. (2004) demonstrated that the saturated hydraulic conductivity (Ks) of an Andisol in southern Chile changed during infiltration showing high variations of surface properties and heterogeneous pore continuity. Ellies et al. (2000) suggested that the saturated hydraulic conductivity can be an indicator of soil structural stability in Chilean Andisols which is strongly related to the stability of soil aggregates.

Soil structure can be adversely affected in the field by chemical and physical disruptive forces. The determination of soil stability often combines these disruptive forces to classify a soil within a qualitative scale, or to allow comparisons between soils.

Structural degradation may be induced by tillage if the soil is cultivated at inappropriate water content, and as a consequence of the loss of organic matter due to oxidation. Permanent cultivation without organic additions can result in loss of micro aggregation, leaving a soil very vulnerable to compaction and erosion. Repeated tillage to the same depth, particularly in clayey soils, can create a smeared and compacted layer just below the tilled soil which can restrict root penetration and soil drainage (Arvidsson, 1997).
Movement of agricultural machinery and animals over soil may result in compaction because of both shear and compressive stresses. Where the soil is unable to support the applied load and shearing predominate deep tracks, ruts and hoof marks will be formed (Arvidsson, 1997). The impact of field traffic depends on the kind and weight of the machinery, number of passes and the speed of traffic, as well as the water content of the soil, its texture and structural characteristics. The effect is often deleterious and the advantages of use of equipment have to be weighed against the benefits of the field operation.

Most studies about the changes in soil structure are focused on the effect of anthropogenic processes such as plowing, amelioration or excavation and reclamation. However, when talking about a structural degradation of grassland soils, the most significant factor that leads to changes in soil properties is animal trampling (Yong-Zhong et al. 2005). Animal trampling led to changes in soil mechanical and hydraulic properties on different scales (from disturbed soil to the structured bulk soil and single aggregate) (Reszkowska, et al, 2011), especially when grazing of livestock occurs at high water content, because the soil is most susceptible to compression and shear deformation and can under those conditions undergo serious modification of its structure (O'Sullivan and Simota, 1995).

The main objective of this study was to describe the hydraulic behaviour of structured volcanic ash soils submitted to wheeling with agricultural tractor at two velocities and two levels of tires inflation rate, with former different levels of cow trampling. In order to describe this behaviour we measured the hydraulic conductivity and total soil porosity. 


\section{Materials and Methods}

\subsection{Location}

The investigation was conducted on prairie soils in Southern Chile, in Austral University farm called Fundo Punahue, located in Los Lagos, $3 \mathrm{~km}$ to Folilco, (704301 E, $5584825 \mathrm{~S}, 155$ m.a.s.1.). According to the Chilean soil classification system, it is defined as Malihue, with undulating topography, silty loam, and well drained to depth, except close to the river, where soils have some drainage restrictions. It is described as Andosol Xilandi-Acroxic (Hiperdistric) (FAO, 1998; Driessen et al., 2001) or Acrudoxic Fulvudand (Soil Survey Staff, 2003). The climatic conditions are as follows: average annual temperature fluctuates between 10.4 and $11.6{ }^{\circ} \mathrm{C}$, rainfall varies between 1551 and $2323 \mathrm{~mm}$ per year.

The soil was trampled by cows, and had two historical managements, before the wheeling experiment was carried out. Site 1, prairie under continuous cut for fodder, with low intensity of animal use, (0.8 - 1 livestock units/ha), Site 2: prairie with intense trampling, with high intensity of animal use, $3-4$ livestock units/ha.

\section{2, Experimental treatments}

Four treatments were imposed on plots $3 \mathrm{~m}$ long and $3 \mathrm{~m}$ wide $\left(9 \mathrm{~m}^{2}\right.$ each one). Each soil plot was wheeled 16 times at the same tracks, measuring the stress distribution by transducer gauges installed in the soil. The experimental variables are as follows: two speeds ( 0.36 and $2.13 \mathrm{~m} \mathrm{~s}^{-1}$ low and high speed, respectively) and two tire inflation pressures, generating two mean contact area pressures (38.7 and $50.1 \mathrm{kPa}$ ) were chosen and defined as low and high inflation, respectively (Table 1). As the effective contact area of the tires varied according to hardness or wetness of the soil, the contact area was defined as elliptical, which allows, using Equation (1) and Figure 1, to calculate the mean contact pressure $(\sigma 0)$ in $\mathrm{kPa}$ (Smith et al, 2000).

$$
\sigma_{0}=\frac{\text { Wheel load } * 0.5 * g}{\pi * a * b} / 1000
$$

Where $\mathbf{g}$ is gravity acceleration $\mathbf{a}$ is Semi major axis $\mathbf{b}$ is semi minor axis

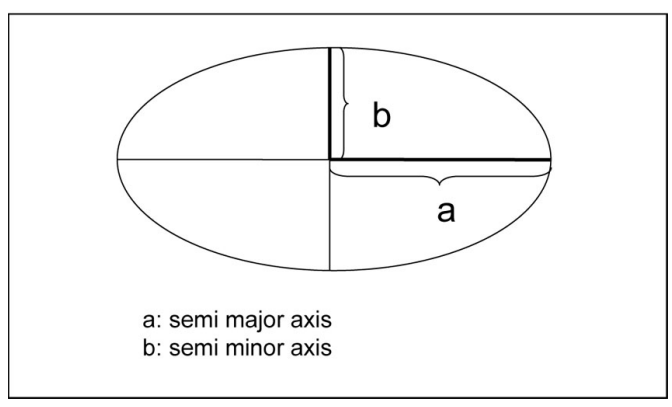

Figure 1. Contact ellipse simulating machinery tire for mean contact pressure $(\sigma 0)$ calculus.

The detailed information about the variations of the contact pressures for each sample at a given soil water content and corresponding matrix potential reveals the strong effect of the water content and pore water pressure as well as of the previous soil management.

\subsection{Collection of undisturbed soil samples}

The soil sampling took place in February 2005. Undisturbed soil samples were taken from 5-10, 20-25 and $35-40 \mathrm{~cm}$ with 6 replicates. The cylinders were 5 $\mathrm{cm}$ high and $8 \mathrm{~cm}$ in diameter.

\subsection{Determination of total soil porosity and pore size distribution}

Distribution of pore size is related to soil matric potential, thus, the air capacity is defined by the very coarse pores ranges $(=\mathrm{pF}$ between $--\infty$ and 1,8), plant available water between $\mathrm{pF} 1,8-4,2$ and non available water $\mathrm{pF}>4,2$ in this the soil porosity in 
first horizon with less trampling is more than soil with more intensive trampling (site 2),

144 undisturbed samples were taken at the same depth and were dried at $105{ }^{\circ} \mathrm{C}$ for 24 hours (Hartge and Horn, 2009) to determine the bulk density. To determine the total porosity, a particle density of 2.65 $\mathrm{Mg} \mathrm{m}^{-3}$ was used, according to Dörner and Dec (2007).

\subsection{Determination of the saturated hydraulic conductivity}

270 undisturbed samples were taken to determine the saturated hydraulic conductivity (Ks). They were measured with a permeameter under steady state conditions. The water flow was measured three times for each soil sample and the arithmetical mean was calculated (Hartge and Horn, 2009).

\subsection{Statistical analysis}

Soil horizon averages were calculated for each treatment. In order to analyze the effect of traffic and previous management on bulk density and soil structure, defined as saturated hydraulic conductivity $\mathrm{Ks}$, statistical analysis was performed by analysis of variance $(p \leq 0.05)$. The differences of means were assessed by the Tukey-Test $(p \leq 0.05)$.

Table 1. Description of treatment over soil

\begin{tabular}{|c|c|c|c|}
\hline \multicolumn{4}{|c|}{ Treatment } \\
\hline Location & Machinery speed & Tire pressure & $\mathrm{N}^{\circ}$ Treatment \\
\hline \multirow{5}{*}{ Site 1} & \multicolumn{2}{|c|}{ Initial (Without machinery traffic) } & 1 \\
\hline & \multirow[t]{2}{*}{ High speed $(2,13 \mathrm{~m} / \mathrm{s})$} & Low $(38,7 \mathrm{KPa})$ & 2 \\
\hline & & high $(50,1 \mathrm{KPa})$ & 3 \\
\hline & \multirow[t]{2}{*}{ Low speed $(0,36 \mathrm{~m} / \mathrm{s})$} & Low $(38,7 \mathrm{KPa})$ & 4 \\
\hline & & high $(50,1 \mathrm{KPa})$ & 5 \\
\hline \multirow{5}{*}{ Site 2} & \multicolumn{2}{|c|}{ Initial (Without machinery traffic) } & 6 \\
\hline & \multirow{2}{*}{ High speed $(2,13 \mathrm{~m} / \mathrm{s})$} & Low $(38,7 \mathrm{KPa})$ & 7 \\
\hline & & high $(50,1 \mathrm{KPa})$ & 8 \\
\hline & \multirow[t]{2}{*}{ Low speed $(0,36 \mathrm{~m} / \mathrm{s})$} & Low $(38,7 \mathrm{KPa})$ & 9 \\
\hline & & high $(50,1 \mathrm{KPa})$ & 10 \\
\hline
\end{tabular}

$\mathrm{m} / \mathrm{s}$ : Machinery speed in meter per second $\mathrm{KPa}$ : pressure in Kilopascal 


\section{Results}

\subsection{General soil description}

The Andisol derived from volcanic ash and its properties are presented in Table 2. Site $1(\mathrm{H1}: 0-21 \mathrm{~cm}$; H2: 21-51 cm; H3: $51-100+\mathrm{cm}$ ) consists of grasses, with a dominating fasciculate root system; while at site 2 (H1:0-25 cm; H2: 25-50 cm; H3: 50-100+ cm) broadleaf species, like Plantago lanceolata and isolated Rubus constrictus, dominate (Ramirez et al. 2005).

No differences exist between both sites in textural classes, and changes by clay enrichment in sub superficial horizons are negligible small. Total porosity is very high because of the internal mineralogical structure of allophane, as the dominant mineral in this soil. Soil aggregation depends on soil management and organic matter content (Ellies et al, 2000). In Site 1, the three horizons have granular to subangular blocky structure. Site 2 which was trampled more intense shows a trampling-induced platy structure in the top $5 \mathrm{~cm}$. The following soil horizons of site 2 have an identical structure as at the site 1 .

Concerning the chemical properties, the results do not show differences between both sites. In general the soil is acid, with an organic matter content ranging between 17 and $5 \%$ (Table 2)

Table 2. Particle size distribution and chemical properties of Andosol under grasses (site 1) and, broadleaf species (site 2).

\begin{tabular}{|c|c|c|c|c|c|c|c|c|c|c|c|c|}
\hline \multirow[t]{2}{*}{ Location } & \multirow{2}{*}{$\begin{array}{c}\text { Depth } \\
\text { (cm) } \\
\end{array}$} & $\begin{array}{c}\text { Sand } \\
(2000-63 \\
\mu \mathrm{m}) \\
\end{array}$ & $\begin{array}{c}\text { Silt } \\
(63-2 \mu \mathrm{m})\end{array}$ & $\begin{array}{c}\text { Clay } \\
(<2 \mu \mathrm{m}) \\
\end{array}$ & SOM & \multicolumn{2}{|c|}{$\mathrm{pH}$} & \multicolumn{2}{|c|}{$\begin{array}{|cc|}\begin{array}{c}\text { N Mineral } \\
(\mathrm{N}- \\
\text { NO3+NH4) }\end{array} & \text { Olsen } \\
\end{array}$} & \multicolumn{2}{|c|}{$\begin{array}{|cc|}\text { K } & \text { Na } \mathrm{Ca} \text { Mg Al } \\
\text { interchangeable }\end{array}$} & CEC \\
\hline & & 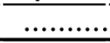 & $\overline{\ldots . . .(g r k}$ & $\left.\mathrm{g}^{-1}\right)$ & & & & $\ldots \ldots \ldots . .\left(m_{z}\right.$ & $\mathrm{g} / \mathrm{kg}) \ldots$ & 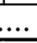 & …........(cmol+/kg). & \\
\hline \multirow{3}{*}{ Site 1} & $0-13$ & 11 & 49 & 40 & 16,5 & 5,6 & 4,8 & 21 & 5 & 47 & $\begin{array}{llll}0,04 & 1,03 & 0,17 & 0,15\end{array}$ & 1,51 \\
\hline & $13-38$ & 9 & 55 & 36 & 7,6 & 5,8 & 5,5 & 11,2 & 2 & 20 & $\begin{array}{llll}0,03 & 1,48 & 0,16 & 0,02\end{array}$ & 1,7 \\
\hline & $38-135+$ & 9 & 53 & 38 & 5,5 & 6 & 5,7 & 15,4 & 2 & 27 & $\begin{array}{llll}0,04 & 3,19 & 0,23 & 0,02\end{array}$ & 3,5 \\
\hline \multirow[t]{3}{*}{ Site 2} & $0-13$ & 10 & 52 & 38 & 16,1 & 5,4 & 4,8 & 18,2 & 8,7 & 43 & $\begin{array}{llll}0,04 & 0,68 & 0,10 & 0,10\end{array}$ & 1,0 \\
\hline & $13-38$ & 9 & 52 & 40 & 8,3 & 5,9 & 5,7 & 14 & 3,7 & 47 & $\begin{array}{llll}0,03 & 2,35 & 0,41 & 0,02\end{array}$ & $2, \mathrm{c}$ \\
\hline & $38-100+$ & 8 & 51 & 41 & 7,3 & 6 & 5,9 & 15,4 & 3,2 & 23 & $\begin{array}{llll}0,03 & 3,15 & 0,71 & 0,02\end{array}$ & 3,97 \\
\hline
\end{tabular}

SOM.: Soil organic matter

Table 3 shows the effect of soil use on the pore size distribution. Both the total porosity and the pore size distribution show the dominance of very coarse pores (=air capacity) while the plant available water is low which is in agreement with the findings of Ellies (2000). The more intense the mechanical stresses applied the more pronounced is the reduction in total soil porosity as well as the stress dependent redistribution of pore of sizes results in reduced air capacity and increased plant available water ( site 1 compared with site 2) throughout the whole soil profile. The fine pore system $(\mathrm{pF}>4.2)$ was not affected by the treatments.

The combined effect of wheeling velocity and applied contact area pressure is summed up in table 5 . 
Table 3. Pore size distribution and aggregate types as a function of mechanical stress applications in Andisols

\begin{tabular}{|c|c|c|c|c|c|c|c|c|}
\hline \multirow[b]{2}{*}{ Site } & \multirow[b]{2}{*}{ Depth $(\mathrm{cm})$} & \multirow[b]{2}{*}{ Horizon } & \multirow[b]{2}{*}{$\begin{array}{c}\text { Bulk } \\
\text { Density } \\
(\mathrm{Mg} / \mathrm{m} 3)\end{array}$} & \multirow[b]{2}{*}{$\begin{array}{c}\text { Soil } \\
\text { porosity } \\
(\%)\end{array}$} & \multicolumn{3}{|c|}{ Pore Size distribution } & \multirow[b]{2}{*}{ Structure } \\
\hline & & & & & Air porosity (\%) & $\begin{array}{c}\text { Plant } \\
\text { available } \\
\text { water } \\
(\%) \\
\end{array}$ & $\begin{array}{c}\text { Water } \\
\text { content } \\
\text { at PWP } \\
(\%)\end{array}$ & \\
\hline \multirow{3}{*}{1} & $0-13$ & Ap & 0,54 & 74,57 a & $26,32 \mathrm{a}$ & $14,74 \mathrm{~cd}$ & $33,28 \mathrm{a}$ & Gra./Bl sub \\
\hline & $13-38$ & B & 0,53 & $77,42 \mathrm{a}$ & $38,23 \mathrm{a}$ & $13,49 \mathrm{bc}$ & $25,69 \mathrm{ab}$ & Gra./Bl sub \\
\hline & $38-48$ & $\mathrm{C}$ & 0,53 & $84,00 \mathrm{~b}$ & $42,66 \mathrm{~b}$ & $10,77 \mathrm{ab}$ & $30,56 \mathrm{a}$ & $\mathrm{Bl}$ sub \\
\hline \multirow{3}{*}{2} & $0-13$ & Ap & 0,64 & $76,74 \mathrm{a}$ & $41,13 a b$ & $9,49 \mathrm{a}$ & $26,11 \mathrm{ab}$ & Bl sub./ Platy \\
\hline & $13-38$ & B & 0,54 & $79,42 \mathrm{ab}$ & $28,80 \mathrm{~d}$ & $22,60 \mathrm{e}$ & $28,00 \mathrm{bc}$ & Bl sub \\
\hline & $38-48$ & $\mathrm{C}$ & 0,48 & $65,92 \mathrm{c}$ & $23,90 \mathrm{c}$ & $18,76 \mathrm{~d}$ & $23,24 \mathrm{a}$ & Bl sub \\
\hline
\end{tabular}

Gra.: Granular; Bl. Sub.: Sub angular blocky; Platy: platy structure. Different letters indicate statistically significant differencesPWP: Permanent wilting point

Table 4. Matric potential (- $\log \mathrm{hPa})$ before wheeling and corresponding water content as a function of depth at both sites.

\begin{tabular}{|c|c|c|c|}
\hline \multirow[t]{2}{*}{ Location } & Depth & \multirow{2}{*}{$\begin{array}{l}\text { Water suction } \\
\text { (Log cm H2O) }\end{array}$} & \multirow{2}{*}{$\begin{array}{c}\text { Water } \\
\text { Content } \\
(\%)\end{array}$} \\
\hline & (cm) & & \\
\hline \multirow[t]{3}{*}{ Site 1} & $0-13$ & 3,17 & 34,78 \\
\hline & $13-38$ & 0,94 & 72,45 \\
\hline & $38-135+$ & 0,12 & 76,96 \\
\hline \multirow[t]{3}{*}{ Site 2} & $0-13$ & 3,24 & 33,64 \\
\hline & $13-38$ & 0,71 & 71,43 \\
\hline & $38-100+$ & 0,67 & 91,93 \\
\hline
\end{tabular}

\subsection{Initial soil conditions previous to wheeling in both sites.}

The soil water content prior to the wheeling experiments was nearly identical at both sites and showed the normal depth depletion. (Table 4)
The functionality of the porous system is characterized by the hydraulic conductivity (Ks) (Figure 2) Mayor differences between sites 1 and 2 can be detected between the 2 sites in the first horizon, where Ks values are significantly smaller by $15 \%$ than at site 1 . In all other horizons no significant differences can be found between the 2 sites.

\subsection{Combined effect of contact pressure and speed of agricultural tractor}

It is not possible to separate the effect of contact pressure exerted on the soil surface and the speed of the tractor; they act synergistically on the values of saturated hydraulic conductivity. Table 5 shows the effect on the hydraulic conductivity at both sites when speed and mean contact pressure is combined. In general Ks values decreased with wheeling and this decrease was the more pronounced the lower the speed and the lower the inflation pressure.

Effect of speed on soil hydraulic conductivity is more pronounced in the first soil horizon while it decreases with depth, which is associated to the mechanical resistance of volcanic soil. 


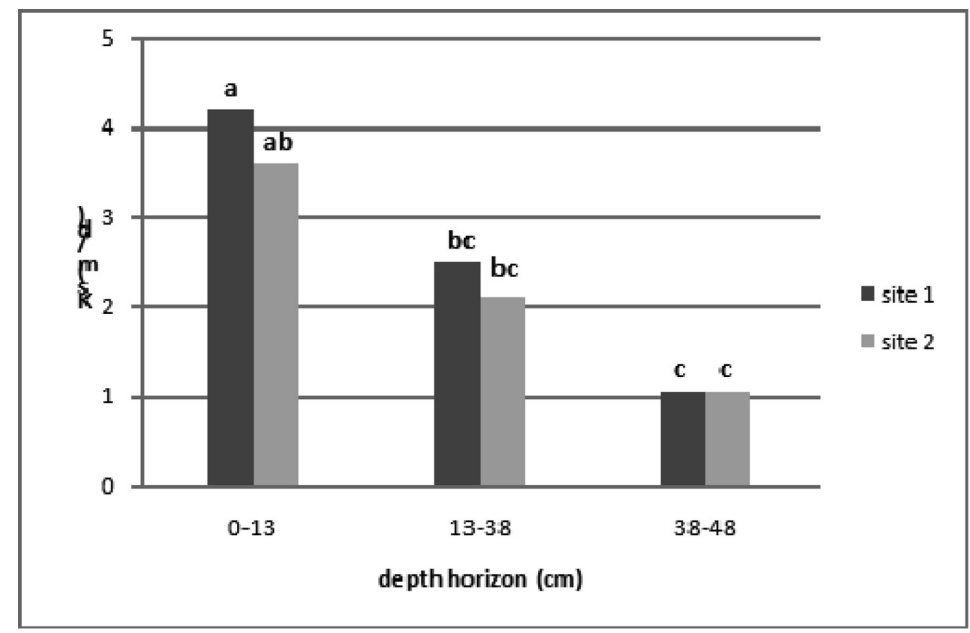

Different letters indicate statistically significant differences

Figure 2. Hydraulic conductivity of soil previously treatment in sites 1 and 2.

Table 5. Effect of wheeling velocity, and inflation pressure (low /high) on saturated hydraulic conductivity $\left(\mathrm{m} *\right.$ day $\left.^{-1}\right)$ in site 1 and 2 .

\begin{tabular}{|c|c|c|c|c|}
\hline \multirow[b]{2}{*}{$\mathrm{N}^{\circ}$ Treatment } & \multicolumn{3}{|c|}{ Depth horizon (cm) } & \multirow[b]{2}{*}{$\begin{array}{c}\text { Complete } \\
\text { profile }\end{array}$} \\
\hline & $0-13$ & $13-38$ & $38-48$ & \\
\hline 1 & $4,65 \mathbf{a}$ & $2,51 \mathbf{b c}$ & 1,03 ef & $2,74 \mathbf{a}$ \\
\hline 2 & 0,63 ef & 2,32 bc & 1,04 bcd & $1,33 \mathbf{~ c d}$ \\
\hline 3 & $0,42 \mathbf{f}$ & $2,95 \mathbf{b}$ & 1,39 def & 1,59 cd \\
\hline 4 & $0,37 \mathbf{f}$ & 0,87 eb & $0,32 \mathbf{f}$ & 0,53 be \\
\hline 5 & $0,33 \mathbf{f}$ & 1,86 cde & 1,01 ef & 1,07 cde \\
\hline 6 & $3,60 \mathrm{~A}$ & $2,10 \mathrm{~B}$ & $1,03 \mathrm{DE}$ & $2,25 \mathrm{~A}$ \\
\hline 7 & $0,44 \mathbf{E F}$ & $1,92 \mathbf{B}$ & $0,21 \mathbf{F}$ & 0,86 BDE \\
\hline 8 & $0,48 \mathbf{E F}$ & $1,54 \mathbf{B C D}$ & $1,12 \mathrm{DE}$ & 1,05 CDE \\
\hline 9 & $0,46 \mathbf{E F}$ & 0,50 EF & $0,06 \mathrm{~F}$ & $0,34 \mathbf{B}$ \\
\hline 10 & $0,47 \mathbf{E F}$ & $1,21 \mathbf{C D}$ & $1,76 \mathbf{B C}$ & 1,15 CDE \\
\hline
\end{tabular}

Different letters indicate statistically significant differences

Capital and small one letter indicate significant differences between Sites. 
Wheeling also affects soil porosity (Table 6) with increasing from without traffic to 16 tractor passes total porosity is reduced, even if the total decline is relatively small. However, between the soil porosity and Ks values we could not detect significant correlations.

Table 6 shows the variation in the total values of pores associated with combined effect of wheeling

Table 6. Total soil porosity (\%) before and after mechanical stress applications.

\begin{tabular}{c|ccc|}
\hline & \multicolumn{3}{|c|}{ Horizon depth (cm) } \\
\hline $\mathbf{N}^{\circ}$ Treatment & $\mathbf{0 - 1 3}$ & $\mathbf{1 3 - 3 8}$ & $\mathbf{3 8 - 4 8}$ \\
\hline 1 & $74,4 \mathbf{a}$ & $77,4 \mathbf{c d}$ & $84,0 \mathbf{b c d}$ \\
2 & $82,1 \mathbf{b c}$ & $81,7 \mathbf{b c}$ & $81,4 \mathbf{b c d}$ \\
3 & $79,4 \mathbf{~ b c d}$ & $78,1 \mathbf{c d}$ & $82,5 \mathbf{~ b c}$ \\
4 & $76,5 \mathbf{d}$ & $82,1 \mathbf{b c}$ & $83,8 \mathbf{~ b}$ \\
5 & $81,9 \mathbf{~ b c}$ & $84,6 \mathbf{b}$ & $82,1 \mathbf{b c}$ \\
\hline 6 & $76,7 \mathbf{A B}$ & $79,4 \mathbf{A}$ & $65,9 \mathbf{~ B C}$ \\
7 & $67,5 \mathbf{A B C}$ & $53,9 \mathbf{D}$ & $63,1 \mathbf{C D}$ \\
8 & $70,1 \mathbf{A B C}$ & $74,9 \mathbf{A B C}$ & $65,8 \mathbf{~ B C}$ \\
9 & $66,2 \mathbf{B C}$ & $62,6 \mathbf{C D}$ & $63,1 \mathbf{C D}$ \\
10 & $75,7 \mathbf{A B}$ & $73,7 \mathbf{A B C}$ & $67,0 \mathbf{~ B C}$ \\
\hline
\end{tabular}

Different letters indicate statistically significant differences Capital and small one letter indicate significant differences between Sites. and load. These changes are minimal if they are analyzed for the complete soil profiles. For the site 1 there are no statistical differences between the treatments while for site 2 differences associated with the loads and tire inflation pressure exist., It is important to emphasize that the site 2 shows minor values of porosity than site 1 , given by the previous site management

\section{Discussion}

Andisols have more abundant coarse pores and water stable aggregates than other soils (Ellies et al, 2000) which also influence the mechanical stability of Andisols by a high degree of interconnection between structural units. The primary and secondary particles of these soils are very rough and have many broken edges, like volcanic glass (Ellies et al., 2000; Ellies et al, 1996). The extremely high water retention of Andisols (up to 85 vol. \% at saturation) has been described repeatedly (Nanzyo et al., 1993, Ellies et al, 1997; Ellies et al, 2000) and is mostly attributed to the presence of amorphous clay minerals such as allophone (Buytaert et al, 2005).

The compaction of these soils apparently does not generate serious problems, because after compaction adequate pore volumes persist to allow appropriate vegetal development. However, excessive tillage, especially with heavy machines, could accentuate summer droughts and the length of the saturation period during winter and spring, because of the loss of coarse porosity, In Chile several corresponding investigations have been conducted and proofed high strength values of these volcanic ash soils (Ellies, 1988; Ellies et al, 1997; Ellies et al, 2000). Trampling or machine induced soil compaction alters not only the total pore volume and the pore size distribution but we have also to include the shear induced changes in the pore continuity and pore functioning. Sillon et al 
(2003) stated that the consequence of soil compaction can be also derived by the higher water content due to reduced hydraulic conductivity in calcareous soil with high bulk densities which is also confirmed by our research for volcanic ash soils. However, soil deformation as the sum of soil shearing and divergent processes (which are defined as soil compaction) can reduce the increase in the bulk density due to wheeling because the shearing (= rearrangement of particles at a given density) can level off these density increases again during the deformation process. The shear induced rearrangement of soil particles up to a complete kneading of the soil under wet or mostly saturated conditions may destroy even the total structure and results in the new generation of e.g. prisms with very wide secondary pores in between. The pores form water channels passing through the profile, like relict structural pores mentioned by Sillon et al (2003). Furthermore, it is well known that because of the reduced pore volume and/or the finer pores those soils remain wetter and are still available over longer time spans. This would explain the change in the retention curve between the compacted plot, the autumn-tilled plot and the spring-tilled plot. In addition, these pores are not interconnected and therefore do not contribute to the transport processes. As a consequence, only a smaller proportion of the water contributes to the water movement in the compacted plot than in the tilled plots. The total pore volume or even the pore size distribution cannot be related directly with the water fluxes as could be shown by the own results. The pore volume or pore size distribution defines only a volume of pores per total soil volume but it is not included the connectivity of the pores in the total soil volume. Thus, it is clear that the hydraulic conductivity is a much more effective parameter for determination of the functioning of pores. If in addition we now also include the stress induced changes we can also explain the significant reduction in hydraulic conductivity in the top soil and the differences between sites 1 and 2. Especially the first horizon is more affected by the contact area pressure and eventually tires slip or shear effects resulting in a kneaded soil surface.
Apart from the effects of stress and shear effects on the changes in the functionality of the soils also the intensity of historical soil management must be considered. As soon as the present stress application exceeds the former strength values the rearrangement of the pores can be contributed to the behaviour in the virgin compression curve range and determines the extra soil deformation, too. If we assume that in the past the trampling by animals was very pronounced than soil structure became mostly homogenized and a next structure formation process begins. Associated with more intensive management and increased trampling by livestock also the hydraulic properties at the time of wheeling is a relic of these formation soil management strategies and affects the hydraulic fluxes over a long time span.

The newly applied stresses now rearrange this "former secondary" pore system and contributes also to differences in changes due to the new stress application. The possible appearance of some fractures in soil is higher in site 1 than site 2 , by the greater mechanical strength shown by the second one; In this context also the combined effect of tractor speed and tire inflation pressure causes differences in the rearrangement intensity and hydraulic functionality.

The changes are more pronounced at low tire inflation pressure and if wheeled slowly. This effect is expected because the stress application occurred longer on the ground and destroys the structure more intense. At site 2, these effects are less pronounced which can be explained by the former history of this site. Finally the vehicle speed affects the hydraulic properties too.

In both sites decreases the values of hydraulic saturated conductivity, under traffic of the tractor with different speeds, this because the speed of the tractor does not exercise a constant pressure for his system of dulling, and in addition for a differential exit of water of the porous system, that according to Ellies et al (1996) it is named an effect of neutral pressures. One explanation is that the porous system collapses under external pressures, which should generate a 
reduction in the amounts of saturated soil hydraulic conductivity; however, as is observed in Table 5, there is a differential soil mechanical behaviour depending on historical management and load in soil surface.

It is to be expected that high speeds generate tractor slip on the soil surface, and this causes the appearance of micro fractures in soil matrix associated with soil deformation. These micro fractures are maintained in the soil samples that are taken to the laboratory for analysis, causing the increase of Ks on site 1.In summary wheel speed and tire inflation pressure are always concerning their effects to be related to the former site history and original soil strength. The additional effects of the present stress application must be compared to those of the former treatments. Irrespective of these interactions the hydraulic functions can be determined by the hydraulic conductivity and not by the pore size distribution because slip induced shearing at a given stress and under a given water saturation may create a very pronounced structure deterioration and a restart of the next generation of aggregates including different pore size and continuities as well as rearrangements of particles within the structure units.

\section{Conclusions}

-Soil porosity in Andisols in southern Chile is related to the land management and is affected by the kind and intensity of mechanization and animal trampling.

-Soil compaction as well as the changes in hydraulic functions depends on the previous stress history.

-With the traffic of the tractor the changes are intensified in the porous system of the soil, this does that there is modified the water content of the soil and his hydraulic properties

- As could be proofed is the hydraulic conductivity a meaningful soil parameter to evaluate the connectivity and functionality (i.e. quality) of soil porosity in order to detect the long term effects of stress application and affected soil deformation.

\section{Acknowledgements}

The authors thank to national Commission for scientific and technological Research (FONDECYT 1043333 Project) by financial support for this research and MECESUP (AUS 9904) by Doctoral Studies support.

\section{References}

Arvidsson, J. 1997. Soil Compaction in Agriculture - From Soil Stress to Plant Stress. Ph.D. thesis. Agraria 41, Swedish Univ. of Agric. Sciences, Uppsala.

Buytaert, W., Wyseure, G., De Biévre, B., Deckers, J. 2005. The effect of land use changes on the hydrological behaviour of Histic Andosols in south Ecuador. Hydrol. Process. 19, 3985-3997

Dörner, J., Dec, D. 2007. Air permeability and saturated hydraulic conductivity as a tool for the functional characterization of soil pores. J. Soil Sc Nutr. 7 (2) 1-13.

Driessen, P., Deckers, J., Spaargaren, O., Nachtergaele., F. 2001. Lecture notes on the major soils of the World. World Soil Resources Reports 94. FAO, Rome.

Ellies, A. 1988. Mechanical consolidation in volcanic ash soils. In: J. Drescher, R. Horn,. M. de Boodt (eds) Impact of water and external forces on soil structure. Catena Supplement 11. pp. 87-92.

Ellies, A., Horn, R., Smith, R. 1996. Transmisión de presiones en el perfil de algunos suelos. Agro Sur (Chile) 24 (2) 149-158.

Ellies, A., Grez, R., Ramírez, C. 1997. La conductividad hidráulica en fase saturada como herramienta para el diagnóstico de la estructura del suelo. Agro Sur 25 (1), 51-56. 
Ellies, A., Horn, R., Smith, R., 2000. Effect of management of a volcanic ash soil on structural properties. International Agrophysics 4: 377-384

FAO, ISRIC and ISSS. 1998. World Reference Base for Soil Resources. World Soil Resources Report 84. FAO, Rome.

Hartge, K.H., Horn, R. 2009. Die physikalische Untersuchung von Böden. 4.ed. Schweizerbarth Verlag, Stuttgart.

Horton, R., M.D, Alkeny,, R.R. Allmaras. 1994. Effects of compaction on soil hydraulic properties. In B.D. Soane and C. van Ouwerkerk (ed.) Soil compaction in crop production. Elsevier, Amsterdam. p. 141-165.

Horgan , G., Ball, B. 2005 Modelling the effect of water distribution and hysteresis on air-filled pore space. European Journal of Soil Science, 2005, 56, 647-654

Janssen, I., Kruemmelbein, J., Horn, R., Ellies, A. 2004. Physical and hydraulic properties of the ñadi soils in south Chile - Comparison between untilled and tilled soil, Revista de la Ciencia del Suelo y Nutrición Vegetal. 4, 14-28.

Moret, D., Arrué, J.L. 2007. Dynamics of soil hydraulic properties during fallow as affected by tillage. Soil Till. Res. 96, 103-113.

Nanzyo, M., Dahlgren, R., Shoji, S. 1993. Chemical characteristics of volcanic ash soils. In Shoji S., Nanzyo M. and Dahlgren R. A. (eds.). Volcanic ash soils. Genesis, properties and utilization. Development in Soil Science 21. Elsevier Science Publishers B.V., Amsterdam, The Netherlands. p.145-187.

O'sullivan, M., Simota, C. 1995. Modelling the environmental impacts of soil compaction: a review, Soil Till. Res. (35) pp. 69-84.
O'sullivan, M., Simota, C. 1995. Modelling the environmental impacts of soil compaction: a review, Soil Till. Res. (35) pp. 69-84

Ramirez, C., San Martin, C., Gruner, C. 2005. Cambios florísticos y vegetacionales con diferentes manejos pecuarios en un suelo Andeptic Palehumults (La Unión, X Región, Chile). Agro sur, 33(2):13-28.

Reszkowska, A., Krümmelbein, J., Peth, S., Horn, R., Zhao, Y., Gan, L. 2011 Influence of grazing on hydraulic and mechanical properties of steppe soils under different vegetation type in Inner Mongolia, China Plant Soil. 340, 59-72.

Sillon, J., Richard, G., Cousin, I. 2003. Tillage and traffic effects on soil hydraulic properties and evaporation. Geoderma, 116, 29- 46.

Smith, R., Ellies, A., Horn, R. 2000. Modified Boussinesq's equations for nonuniform tire loading. Journal of Terramechanics, 37, 207-222.

SOIL SURVEY STAFF. 2003. Keys to soil taxonomy. Ninth Edition. USDA, Natural Resources Conservation Service. 332 p.

Vervoort, V., Cattle, S. 2003 Linking hydraulic conductivity and tortuosity parameters to pore space geometry and pore-size distribution. Journal of Hydrology. 272, 36-49.

Yong-Zhong, S., Yu-Lin, C., Jian-Yuan., Wen-Zhi, Z. 2005. Influences of continuous grazing and livestock exclusion on soil properties in a degraded sandy grassland, Inner Mongolia, northern China. Catena, 59, 267-278. 